\title{
Making A Web-Based Application For Sales Kitchen Bunda Ghina Using Php And Mysql
}

\author{
Adam Huda Nugraha \\ Faculty of Computer Science and Information Technology, Gunadarma University, Indonesia \\ * Corresponding author: \\ Email:adam_huda@staff.gunadarma.ac.id

\begin{abstract}
Mother Ghina's kitchen is located in Teluk Low Pasar Village, Tebo Ilir District, Jambi Province. When transacting, store sellers still use simple media for information delivery, such as WhatsApp, Facebook and word of mouth. The purpose of creating this application is to expand promotional media and make it easier for consumers from inside and outside the city to place orders online. In the process of creating the website using PHP programming language and Mysql as database. The final stage is to conduct a trial over the Internet.
\end{abstract}

Keywords: PHP, Mysql, Database

\section{INTRODUCTION}

Currently, information technology is not only growing rapidly, but also often changes very quickly. With technological advances that are increasingly rapidly today, it can be said that information technology has entered all fields, one of which is in the field of business. Many business people use information technology to support business progress and earn profits.Mother ghina's kitchen is located in Teluk Low Pasar Village, Tebo Ilir District, Jambi Province. This shop sells various kinds of cakes, including sponge cakes, donuts, brownies, and various traditional Jambi cakes.In conducting transactions, shop sellers still use simple information delivery media, such as whatsapp, facebook and word of mouth.

So that the marketing of products and services is still not optimal. Besides, there are obstacles for customers who are out of town, in which they have to contact one of the contacts of Mrs. Gina first to place an order. This of course also makes it difficult for the store to record incoming orders from several social media accounts. This is what might need to be changed in promoting products to make them more affordable for customers who want convenience in buying products. So it is necessary to have a web-based sales system that is more dynamic to facilitate the promotion of goods and consumers who are inside or outside the city can directly place orders through the website without having to contact Ibu Ghina's kitchen contact first and speed up the process of buying and selling products.

\section{LITERATURE REVIEW \\ Definition of E-Commerce}

According to Panca (2018). "Electronic commerce is a new concept that is usually described as the process of buying and selling goods and services on the World Wide Web or exchanging products, services and information through information networks including the internet."E-commerce is one of the advantages of the internet, until finally in this current era (which is called the digital era) e-commerce has many names, namely internet commerce, e-com, e-commerce or immerce which means buying or selling electronically, and this activity is carried out on the internet network.

\section{Benefits of E-Commerce}

1. Benefits for the company.

a. Expand sales reach

b. Reduce operational costs

2. Benefits for consumers.

a. Allows customers to shop or make other transactions for 24 hours. 
b. It's easier to choose a variety of products even if you don't come directly to the store.

3. Benefits for the community.

a. Allows people to work from home and not have to leave the house to shop.

b. Allows a number of goods to be sold at lower prices so that poor people can buy more which in turn will improve their standard of living

Types of E-commerce.

1. Business to Business (B2B). This type of e-commerce includes transactions between organizations that are carried out in the electronic market.

2. Business to Customer (B2C). Represents retail transactions with individual buyers.

3. Customer to Customer (C2C). Consumers sell directly to other consumers, or advertise personal services on the Internet.

4. Customer to Business (C2B). Individuals who sell products/services to organizations, individuals who are looking for sellers to interact and agree on a transaction.

\section{Advantages of Electronic Commerce (E-Commerce).}

There are several advantages that can be taken from the use of E-commerce, namely:

1. Electronic commerce allows customers to shop or make other transactions 24 hours a day all year round from almost any location.

2. Electronic commerce gives customers more choices, they can choose various products from many vendors.3. Electronic commerce provides customers with inexpensive products and services by visiting many places and making quick comparisons.

\section{PHP (PHP: Hypertext Preprocessor)}

Is a programming language whose commands are executed by the server and then the results are displayed on the client computer. PHP is also embedded HTML, that is, PHP syntax is written together with HTML syntax. So PHP and HTML are a synergy of two mutually reinforcing programming languages. Although some people think HTML is not a programming language.

PHP is also an open source programming language that can be downloaded for free. Until now, the latest version of PHP is version 7.0.8, which can be downloaded on the official PHP website http://php.net/downloads.php.

\section{RESEARCH METHOD}

\section{User Navigation Structure Design}

In the navigation structure, the user uses a mixed navigation structure between hierarchical and nonlinear user navigation structures that are made as shown in Figure 3.1.

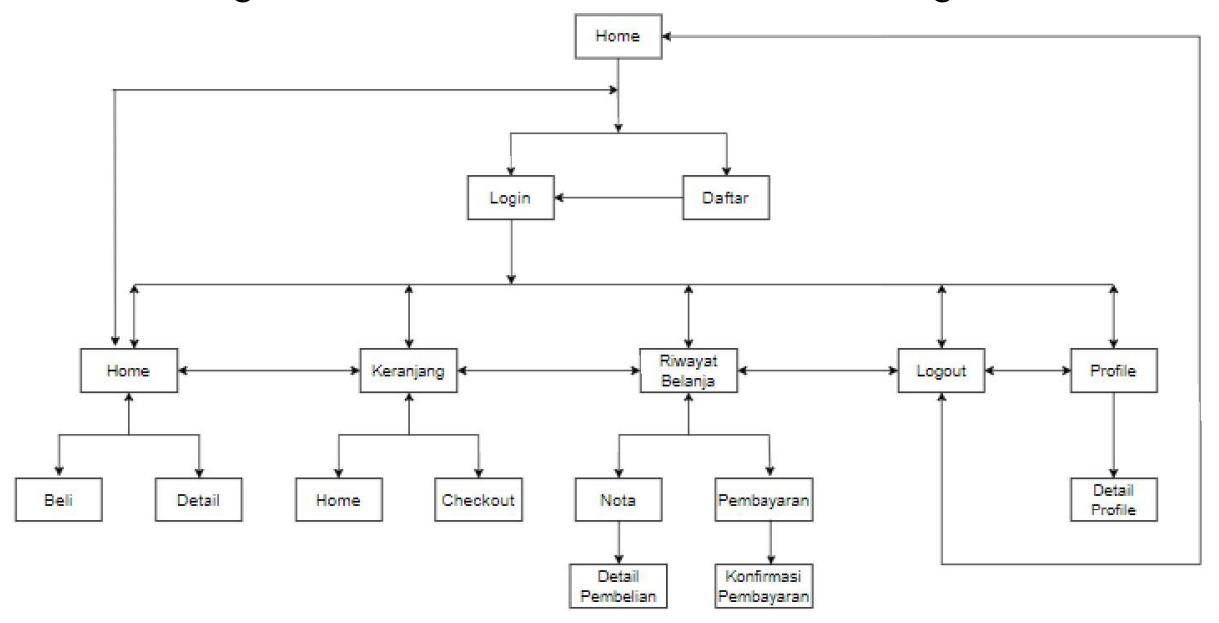

\section{Admin Navigation Structure}

The Admin Navigation Structure uses a mixed navigation structure between hierarchical and nonlinear. The navigation structure is made as shown in Figure 3.2. 


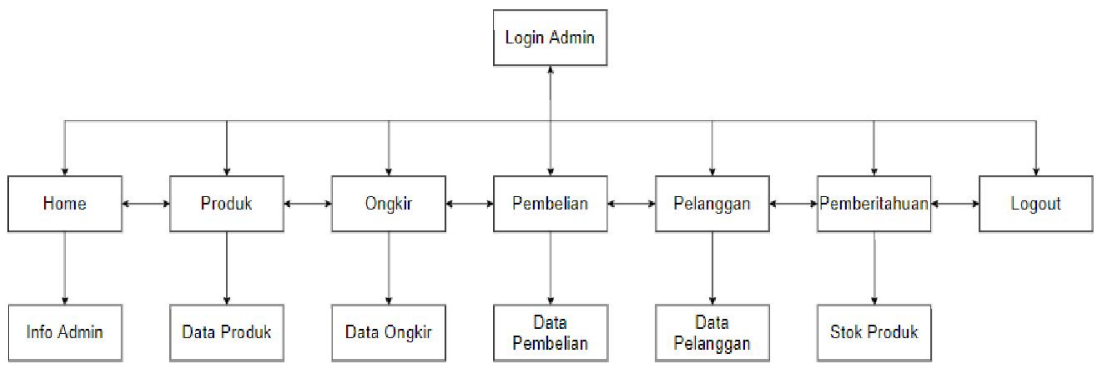

\section{UML Design}

UML design by applying Use Case Diagrams to describe the interaction between users and applications and find out the functions of the features available in the application

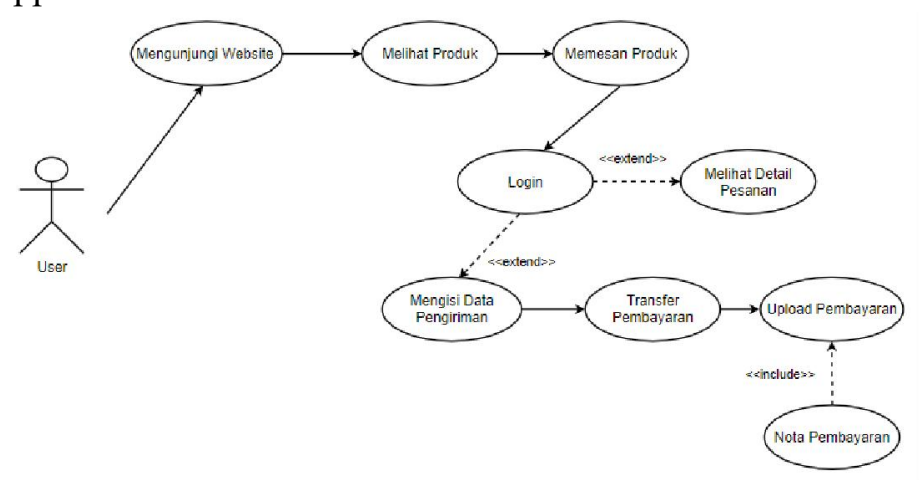

Use Case Diagram User

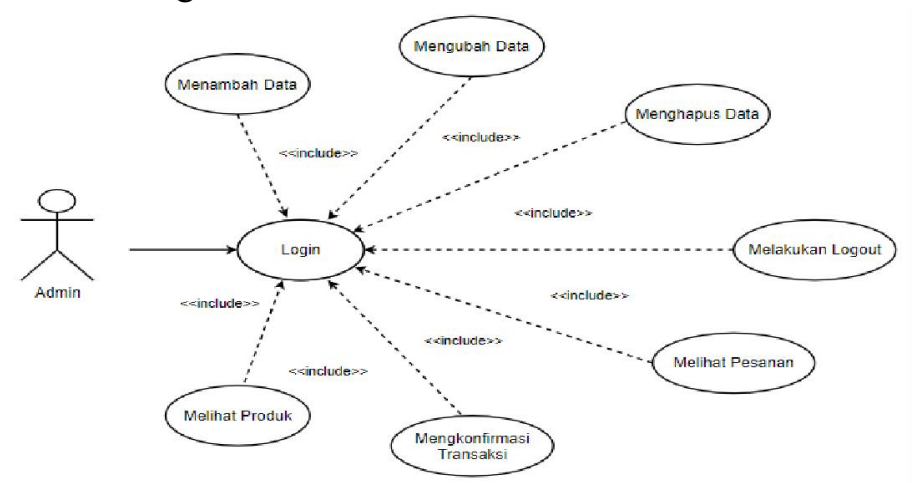

Use Case Diagram Admin

\section{RESULTS AND DISCUSSIONS \\ User Login Page}

Fig 4.1. is a picture of the user login page on the Ibu Ghina kitchen website. In the login screen, there are four menus, namely home, basket, login, and list. The login page displays a form for user login with two textboxes to enter email and password. There is one button to login.
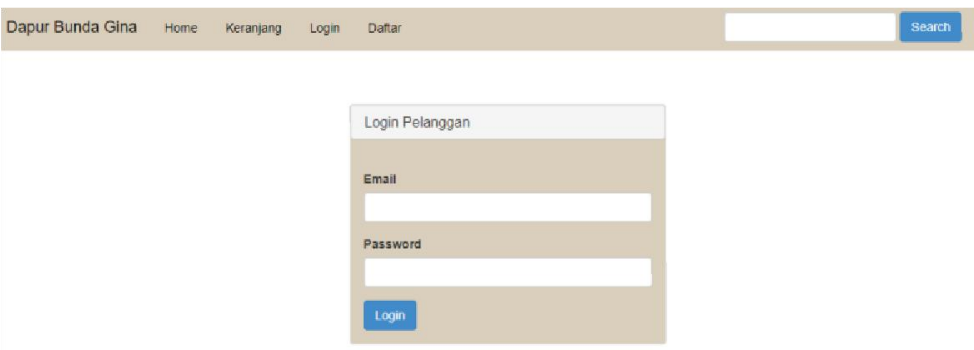

Below is a function to create an email and password textbox, and a login button:

$<$ div class="panel-body" $>$

$<$ form method="post" $>$ 
$<$ div class="form-group" $>$

$<$ label $>$ Email $<$ label $>$

$<$ input type="email" class= "form-control" name="email" $>$

$<$ div $>$

$<$ div class="form-group" $>$

$<$ label $>$ Password $<$ label $>$

$<$ input type="password" class="form-control" name="password" $>$

$</$ div $>$

$<$ button class="btn btn-primary" name="login" $>$ Login $<$ button $>$

$</$ form $>$

$</$ div $>$

\section{Home Page After User Login}

Fig 4.2. is a picture of the home page after the user logs in on the website of Bunda Ghina's kitchen. On the home screen after user login, there are five menus, namely home, basket, shopping history, logout and profile. the home page after logging in shows a slide, the latest product, the buy button and the detail button.

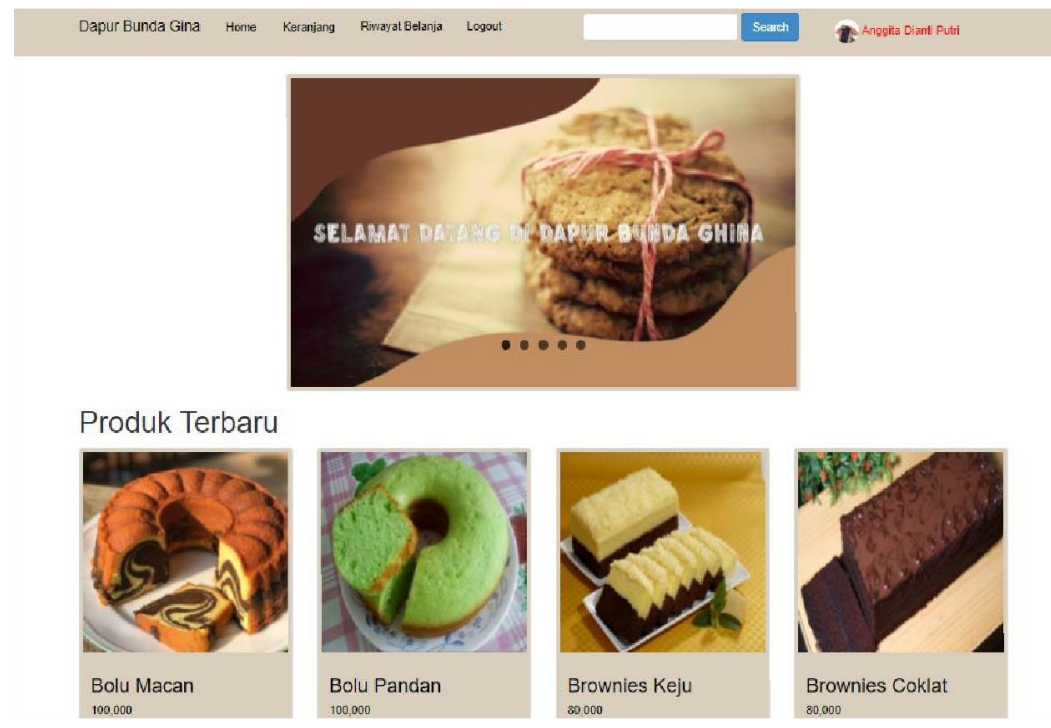

Below are functions to display slides, latest products, and create buy buttons and detail buttons:

$<$ section class="konten" $>$

$<$ ?php include 'slide.php'; ?>

$<$ h1 $>$ Produk Terbaru $<$ h1 $>$

$<$ div $><$ div class="add-to-cart" $>$

$<$ ?php

if(\$perproduk['stok_produk']>=1)\{

?>

$<\mathrm{a}$ href="<?=(\$perproduk['stok_produk']) ? "beli.php?id=\$perproduk[id_produk]" : "\#" ?>"> <button class="btn btn-primary" $><\mathrm{i}></ \mathrm{i}>$ Beli $</$ button $></ \mathrm{a}>$

$<$ ?php $\}$ ? $>$

$<$ a href="detail.php?id=<?php echo \$perproduk["id_produk"]; ?>" style="background-color: \#008080" class="btn btn-default" $>$ Detail $</ a>$

$</$ div $>$

$</$ div $>$

$<$ div $>$

$<$ ?php \} ?> 


\section{Admin Login Page}

Fig 4.3. is an image of the admin login page on the mother ghina kitchen website. In the admin login screen, there is a username and password textbox, a login button to enter the admin home page.

Dapur Bunda Ghina

( Login yourself to get access)

Enter Details To Login

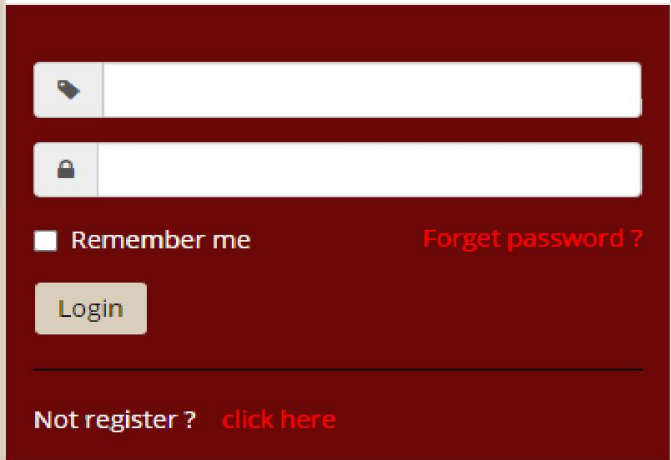

Below is a function for the admin username and password textbox:

$<$ div class="form-group input-group" $>$

$<$ span class="input-group-addon" $><$ i class="fa fa-tag" $></ \mathbf{i}></$ span $>$

$<$ input type="text" class="form-control" name="user" $/>$

$</$ div $>$

$<$ div class="form-group input-group" $>$

$<$ span class="input-group-addon" $><$ i class="fa fa-lock" $></ \mathbf{i}></$ span $>$

$<$ input type="password" class="form-control" name="pass" $>$

$</$ div $>$

Fig 4.4. Is a picture of the admin home page on the mother ghina kitchen website. On the left side of the admin home screen, there are home menus, products, shipping, purchases, customers, notifications and logout. While in the middle there is a welcome word and admin information.

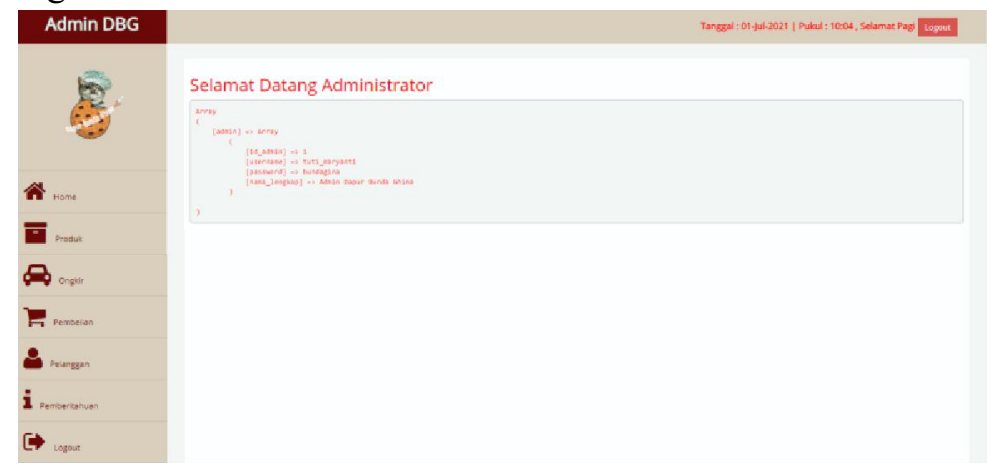

Below is a function to display welcome, and admin information:

$<$ h2 $>$ Selamat Datang Administrator $</$ h2 $>$

$<$ pre $><$ ?php print_r(\$_SESSION); ? $><$ pre $>$

\section{CONSLUSION}

The Bunda Ghina Kitchen website has been successfully created to display an order catalog and payment confirmation. And has been tested on three browsers with the results running well.This website has also gone through the hosting stage with the domain kitchenbundaghina.rf.gd, in order to help the Dapur Bunda Ghina who still uses simple information delivery media, such as whatsapp, facebook and word of 
mouth. can now market its products to a wider market, and gradually increase sales turnover. As well as giving prospective buyers the convenience of getting information about the products being sold, as well as being able to easily place orders on the website page.

\section{SUGGESTIONS}

This website can be further developed by adding chat facilities with admins, maps, categories, and improving the appearance to make it look more attractive.

\section{REFERENCES}

[1] Haviluddin, Haviluddin. "Aplikasi Program PHP dan MySQL." (2016).

[2] Yanto, Robi. Manajemen Basis Data Menggunakan MySQL. Deepublish, 2016.

[3] Solichin, Achmad. Pemrograman web dengan PHP dan MySQL. Penerbit Budi Luhur, 2016.

[4] Astuti, Dewi, and Febi Nur Salisah. "Analisis kualitas layanan e-commerce terhadap kepuasan pelanggan menggunakan metode e-servqual (studi kasus: Lejel home shopping pekanbaru)." Jurnal Ilmiah Rekayasa dan Manajemen Sistem Informasi 2.1 (2016): 44-49.

[5] Haerulah, Edi, and Sri Ismiyatih. "Aplikasi E-Commerce Penjualan Souvenir Pernikahan Pada Toko "XYZ"." PROSISKO: Jurnal Pengembangan Riset dan Observasi Sistem Komputer 4.1 (2017).

[6] Simajuntak, Pastima. "Analisis Model View Controller (Mvc) Pada Bahasa Php." Journal Information System Development (ISD) 1.2 (2016).

[7] Ayu, Fitri, and Nia Permatasari. "Perancangan Sistem Informasi Pengolahan Data PKL (Praktek Kerja Lapangan) Di Devisi Humas Pada PT Pegadaian." Jurnal Intra Tech 2.2 (2018): 12-26.

[8] Susilo, Muhammad. "Rancang Bangun Website Toko Online Menggunakan Metode Waterfall." InfoTekJar: Jurnal Nasional Informatika dan Teknologi Jaringan 2.2 (2018): 98-105.

[9] Shahnaz, Nanda Bella Fidanty, and Wahyono Wahyono. "Faktor Yang Mempengaruhi Minat Beli Konsumen Di Toko Online." Management Analysis Journal 5.4 (2016).

[10] Panca, Panca. "Membuat Aplikasi E-commerce untuk Sebuah Toko Obat dengan Menggunakan PHP Dan MySql." Jurnal Ilmiah KOMPUTASI 17.3 (2018): 255-264. 